\title{
45. LATE PLIOCENE-PLEISTOCENE PALEOCLIMATE IN THE JANE BASIN REGION: ODP SITE $697^{1}$
}

\author{
Lloyd H. Burckle, ${ }^{2}$ Rainer Gersonde, ${ }^{3}$ and Nelson Abrams ${ }^{4}$
}

\begin{abstract}
We examined diatom preservation patterns in Pliocene age sediments of Jane Basin (ODP Site 697) and compared them with diatom distribution in more northerly sites at various sectors of the Southern Ocean. Our data from Site 697, as well as other sites from around the Southern Ocean, support the view that there was significant ice growth on Antarctica during the late Pliocene. DSDP Site 514 in the Atlantic sector shows increased relative abundance of Eucampia antarctica, an ice-related form, in the upper part of the Gauss Chron with a larger increase just above it. With one exception, all sites included in the present study show increased relative abundance of $E$. antarctica in the upper part of the Gauss. Our view that there was ice growth on Antarctica during the late Gauss Chron is supported by the results from ODP Site 697. While diatoms are present and percent opal is high in the early and middle Gauss Chron (suggesting more open-ocean conditions), late Gauss sediments contain low percentages of opal and few or no diatoms. This is also true for the early Matuyama Chron. If we accept spring and summer sea-ice cover as the major suppressant of diatom productivity in the Southern Ocean, then we conclude that sea-ice covered the region around Site 697 through much of the year during this interval. Further, the absence of diatoms and the low percentages of opal in middle and late Matuyama chron sediments suggests increased sea-ice cover over the Jane Basin during this time. Although warmer openocean intervals are inferred for intervals near the Olduvai and Jaramillo Subchrons, most of the Matuyama Chron was marked by extensive sea-ice cover with low seasonal contrast. Our results for the early part of the Brunhes Chron are similar, at least for the Jane Basin. During this time, sea-ice cover over the basin apparently extended well into the growing season. In contrast, the later Brunhes Chron is marked by alternating open water (during the growing season) and extensive, almost year-round, sea-ice.
\end{abstract}

\section{INTRODUCTION}

Because seasonal changes in sea-ice are an important element dictating present-day climate, knowledge of its distribution in the Southern Ocean during the late Tertiary is important in paleoclimatology and paleoceanography and will help us to understand the evolution of the climate system. For that reason, it is important to evaluate and/or identify proxy indicators of sea-ice and water mass boundaries in the water column in both surface and late Tertiary sediments of the Southern Ocean. For the late Pliocene, ice-sheet growth is largely seen as a Northern Hemisphere phenomenon. The cooling, which began at about 3.1 Ma (Backman and Pestiaux, 1987; Raymo et al., 1987; Einarsson and Albertsson, 1988) resulted in the accumulation of successively larger ice-sheets, finally culminating in the first extensive ice-rafting in the open ocean North Atlantic at $2.4 \mathrm{Ma}$ (Backman, 1979; Shackleton et al., 1984). Using oxygen isotope data, Raymo et al. (in press) noted that the late Pliocene record between about 2.4 and $1.6 \mathrm{Ma}$ was marked by ice volume changes primarily at the $41 \mathrm{k} . \mathrm{y}$. rhythm of orbital obliquity. This was also true of the interval prior to $2.4 \mathrm{Ma}$ but the amplitude in the 41 k.y. rhythm gradually increased towards $2.4 \mathrm{Ma}$. The cooling that began at $2.4 \mathrm{Ma}$ was marked by three cycles at 41 k.y. rhythm, followed by at least six low-amplitude cycles, also at 41 k.y. rhythm. According to Raymo et al. (in press) the late Pliocene ice-sheets younger than $2.4 \mathrm{Ma}$ were, on average, one half as large as those of the late Quaternary.

\footnotetext{
${ }^{1}$ Barker, P. F., Kennett, J. P., et al., 1990. Proc. ODP, Sci. Results, 113: College Station, TX (Ocean Drilling Program).

${ }^{2}$ Lamont-Doherty Geological Observatory, Palisades, NY 10964.

3 Alfred Wegener Institut für Polar und Meeresforschung, Postfach 120161, D-2850 Bremerhaven, Federal Republic of Germany.

${ }^{4}$ Department of Geology, Rutgers University, Newark, NJ 07102.
}

Although it is generally conceded that there was Southern Hemisphere cooling in the late Pliocene it is not known to what extent changes in size of the Antarctic ice-sheet contributed to the oxygen isotope record. Kennett (1977), for example, has argued that East Antarctica began accumulating significant continental ice when the initiation of the Antarctic Circumpolar Current thermally isolated the continent. Although the ice-sheet has fluctuated in size since the middle Miocene, it has not, according to this author, undergone any significant partial deglaciation during the past 14-15 m.y.

Site 697 in the Jane Basin is well suited to investigate, in part at least, the Antarctic contribution to late Pliocene global cooling and glaciation (see Barker, Kennett, et al., 1988, for physical setting of Jane Basin). Schwerdtfeger (1975) notes that the Weddell Sea is presently the main sea-ice producing region of the Southern Ocean. When stable air masses move westward over the ice-covered Weddell Sea they are blocked by the mountains of the Antarctic Peninsula. This produces a strong surface wind flow from the southwest (the barrier winds), which drives seaice and icebergs toward the north and northeast. Besides being in the track of icebergs and sea-ice advected northward under the influence of these barrier winds and the Weddell Gyre, this region is also a pathway for Antarctic Bottom Water (AABW) streaming down off the Weddell shelf (Gordon, 1971; Pudsey et al., 1988). In addition to having sedimentological characteristics reflecting winnowing and iceberg movements, sediments in the underlying Jane Basin may also reflect diatom productivity patterns dictated by the presence or absence of sea-ice during the growing season (i.e., during the austral spring and summer).

\section{Background}

The basic sediment pattern of the Southern Ocean (both biogenic and nonbiogenic) has been known since the work of Murray and Renard (1891). These authors noted that Antarctica is surrounded by a belt of largely terrigenous sediment that ex- 
tends as far north as $60^{\circ} \mathrm{S}$. To the north, this terrigenous sediment is bounded by a zone of biosiliceous ooze which extends to about $50^{\circ} \mathrm{S}$. North of this belt, depending upon water depth, biocalcareous ooze or red clay occurs. Philippi (1912) was the first to observe that these sedimentary patterns changed over recent geologic time. He found biocalcareous sediment overlying biosiliceous oozes in cores raised from north of the Polar Front and, in cores raised from south of the front, biosiliceous oozes overlying glacial marine sediment. This apparent northward displacement of sediment zones was attributed to both increased continental ice and sea-ice during glacial intervals. Schott (1939) argued that the upsection change from glacial marine sediment to diatom ooze was due to a decrease in iceberg rafting of continental material and that the upsection change from diatom ooze to Globigerina (biocalcareous) ooze was due to southward movement of the Polar Front.

More recent work has served to refine these earlier observations. Hays et al. (1976) used new biostratigraphic data to demonstrate that the youngest diatom ooze was deposited during the Holocene while the underlying diatomaceous clay represented glacial conditions. Additionally, they suggested that the diatomaceous clay was probably deposited during periods of greater sea-ice cover. Using both bio- and lithostratigraphy to identify relative time intervals, they concluded that sea-ice cover during full glacial episodes greatly exceeded present day cover by a factor of four or five.

Diatom species and assemblages in late Quaternary sediments have also been used to identify sea-ice conditions or seaice limits around Antarctica. Burckle (1984), for example, used high relative abundance of resting spores of Eucampia antarctica to infer increased wintertime sea-ice concentrations during the Last Glacial Maximum (LGM) in the Atlantic sector of the Southern Ocean. His winter LGM sea-ice margin did not differ greatly from that of Cooke and Hays (1982). Pichon et al. (1987) used geographically restricted diatom assemblages in surface sediments to identify summer sea-ice conditions and suggested that this approach may be useful in determining summer sea-ice limits during the LGM.

Burckle et al. (1987), Burckle and Cirilli (1987), and Shemesh et al. (1989) suggested that diatom dissolution may also be a useful tool for identifying oceanic fronts and sea-ice limits, at least for specific intervals of the year (i.e., early spring). Burckle and Cirilli (1987), for example, identified a diatom dissolution boundary beneath the northern limit of spring sea-ice and suggested that it may be useful in identifying such limits in the late Quaternary record. This dissolution boundary was approximately coincidental with the summer sea-ice boundary as defined by Cooke and Hays (1982; see also, Burckle et al., 1982). From water column data, Burckle and Cirilli (1987) determined that the presence of at least $75 \%$ sea-ice cover through much of the growing season is reflected in reduced diatom accumulation and, hence, apparent increased diatom dissolution on the underlying sea floor. Furthermore, they noted that open-ocean diatoms are abundant in surface sediments beneath regions south of the Subantarctic Front where there is little or no sea-ice during the biologically productive season.

These observations have been quantified in other parts of the world's ocean. Leinen et al. (1986), for example, measured percent biogenic opal in surface sediments and showed a close correspondence to biogenic (largely diatom) productivity in the overlying waters. A number of authors (Molina-Cruz and Price, 1977; Leinen, 1979; Brewster, 1980; Heath et al., 1983; Banahan and Goering, 1986) demonstrated temporal and spatial variations in opal accumulation related to shifts in productivity. Mortlock and Froelich (in press) concluded that the percent opal content in sediment carries a valuable paleoceanographic message related to surface water productivity. Since diatoms make up the bulk of biosiliceous sediment we believe that temporal or spatial changes in percent opal largely reflect changes in productivity patterns in this group. These authors also noted that the systematic error due to clay contamination in opalbearing sediments is on the order of $2 \%-3 \%$. However, we cannot as yet rule out sedimentological processes (i.e., the amount and nature of detrital influx and sediment winnowing).

From these various published data sets and observations it appears that the relationship between overlying sea-ice concentrations and diatom accumulation and/or preservation on the sea floor within the late Neogene can be described as follows:

1. Sediments taken from localities near the Antarctic continent and which contain no diatoms or few, poorly preserved, diatoms (and also have low percentages of opal) indicate the presence of $75 \%$ or more sea-ice in the overlying surface waters during much of the growing season (i.e., surface-water diatom productivity is suppressed by the presence of sea-ice). This does not include areas, such as submarine canyons and the continental slope, where bottom processes may affect sediment distribution.

2. Sediment with increased relative abundance of resting cells of Eucampia antarctica indicate a short growing season with $\sim 20 \%$ to $<75 \%$ sea-ice present during the summer. The lower end of this percentage range should be viewed with caution, however, since Shemesh et al. (1989) have shown that relative abundance values as high as $10 \%$ may be due to differential dissolution and may be unrelated to suppression of productivity by sea-ice.

3. Sediments containing high opaline silica content (usually in excess of 20\%) and abundant open-ocean diatoms such as Nitzschia kerguelensis and Thalassiosira lentiginosa indicate at least 4-6 months per year of essentially ice-free conditions over the site. The data of Shemesh et al. (1989) suggest that sediments in which $T$. lentiginosa is relatively more abundant than $N$. kerguelensis probably seldom had sea-ice in the overlying waters.

In the present study, these three relationships are used to interpret the paleoclimatic significance of diatoms in middle and late Pliocene sections of the circum-Antarctic region, as well as the late Pliocene-early Pleistocene section of Site 697 in the Jane Basin. At Site 697, we focus on the persistence of sea-ice over the Jane Basin area during this time interval.

\section{SOURCE OF MATERIALS AND PREPARATION METHODS}

Diatoms from four piston cores and two DSDP/ODP sites were examined (Table 1; Fig. 1). Core E13-3 is from the Pacific sector of the Southern Ocean (Hays and Opdyke, 1967), while Cores E38-7, E38-8, and E50-33 are from the southeast Indian sector (Osborn et al., 1982; Burckle and Abrams, 1987). ODP Holes 697A and 697B are from the Atlantic sector (Jane Basin)

Table 1. Location and depth of all sites used in this study.

\begin{tabular}{lccc}
\hline \multicolumn{1}{c}{ Site } & Latitude & Longitude & $\begin{array}{c}\text { Water } \\
\text { depth } \\
(\mathrm{m})\end{array}$ \\
\hline E13-3 & $57^{\circ} 00.3^{\prime} \mathrm{S}$ & $89^{\circ} 29.0^{\prime} \mathrm{W}$ & 2785 \\
E38-7 & $61^{\circ} 48.8^{\prime} \mathrm{S}$ & $149^{\circ} 54.1^{\prime} \mathrm{E}$ & 2000 \\
E38-8 & $61^{\circ} 46.4^{\prime} \mathrm{S}$ & $149^{\circ} 58.7^{\prime} \mathrm{E}$ & 1800 \\
E50-33 & $61^{\circ} 05.1^{\prime} \mathrm{S}$ & $170^{\circ} 03.8^{\prime} \mathrm{E}$ & 2488 \\
DSDP 514 & $46^{\circ} 02.7^{\prime} \mathrm{S}$ & $26^{\circ} 53.1^{\prime} \mathrm{W}$ & 4318 \\
ODP 697A & $61^{\circ} 48.6^{\prime} \mathrm{S}$ & $40^{\circ} 17.2^{\prime} \mathrm{W}$ & 3480 \\
ODP 697B & $61^{\circ} 48.2^{\prime} \mathrm{S}$ & $40^{\circ} 17.74^{\prime} \mathrm{W}$ & 3480 \\
\hline
\end{tabular}




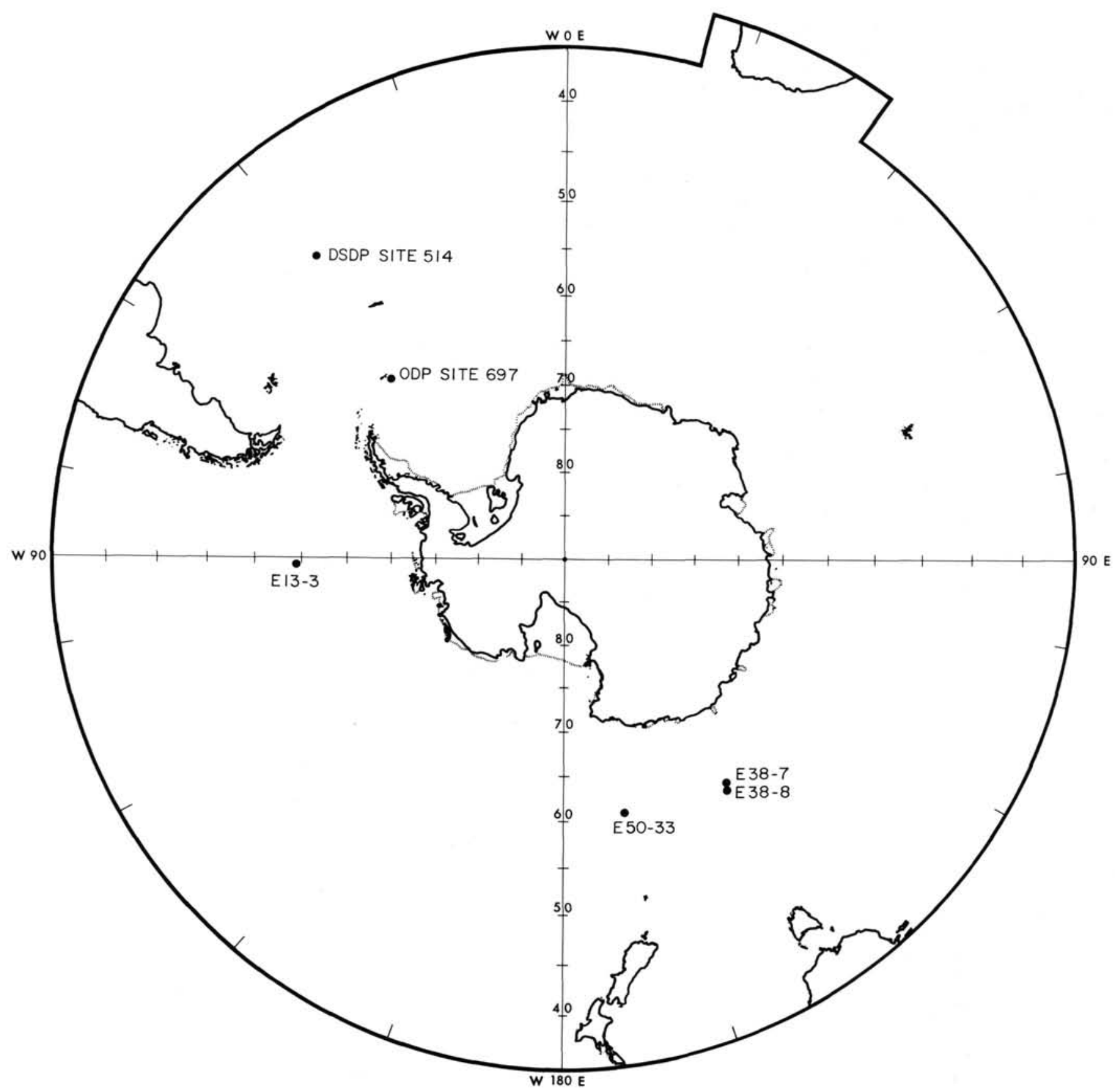

Figure 1. Map of the Southern Ocean showing distribution of piston cores and DSDP/ODP sites used in this study.

and DSDP Site 514 is from the southeastern part of the Argentine Basin. ODP Site 697 and DSDP Site 514 serve as the two (and only) end members of a north to south traverse in the Atlantic sector. Piston cores were sampled at $10 \mathrm{~cm}$ intervals and diatom slides were prepared using procedures described by Schrader (1974). The DSDP/ODP sites were sampled at $\sim 50 \mathrm{~cm}$ intervals and also prepared after Schrader (1974). Opal determinations were made using methods described by Mortlock and Froelich (in press). A minimum of 300 specimens was counted for each sample. In addition to using the shipboard biostratigraphic data, we counted diatoms in two categories: ice-related forms and all others. Essentially this amounted to a comparison between $E$. antarctica and all others since the former was the only ice-related species present in any significant numbers. We also noted the presence of such open-ocean species as $N$. kerguelensis and T. lentiginosa. The former species is also found in and near sea-ice; however, its maximum abundance is in an open-ocean environment south of the Subantarctic Front but north of the Antarctic Slope Front (Burckle et al., 1987).

\section{STRATIGRAPHY}

An upper Pliocene to Pleistocene diatom biostratigraphy for the Southern Ocean has been established by a number of workers, is directly tied to magnetostratigraphy, and has been refined 
by Ciesielski (1983). The primary purpose of this contribution is to quantitatively describe diatom floras associated with the Gauss/Matuyama paleomagnetic reversal boundary. Figure 2 shows the percent abundance of Cosmiodiscus insignis relative to the Gauss Chron in Core E13-3 from the Pacific sector south of the Polar Front (magnetostratigraphy from Hays and Opdyke, 1967). Although this species ranges above the Gauss Chron, its abundance distribution is marked by a sharp drop near the top of the Gauss. This may be referred to as a Last Abundant Appearance Datum (LAAD; Burckle et al., 1978). Figure 3 shows the same relationship in Core E50-33 (also south of the present Polar Front) from the southeast Indian sector. This core also shows a modest increase in abundance of $E$. antarctica concomitant with the abundance drop-off of $C$. insignis. This former species, which is an ice-related form (Burckle, 1984), decreases in abundance in the early Matuyama and then increases in abundance near the Brunhes/Matuyama boundary.

Figure 4 shows a similar relationship in Core E38-8, also from the southeast Indian Ocean. This core has high relative abundance of $E$. antarctica suggesting increased summer sea-ice cover. Although the magnetostratigraphy on this core is suspect (Osborn et al., 1982; Burckle and Abrams, 1987), the Gauss/ Matuyama boundary probably occurs at $\sim 110-120 \mathrm{~cm}$ depth. Similarly, based upon biostratigraphy, Core E38-7 (Fig. 5) from the southeast Indian Ocean also appears to have the Gauss/Matuyama boundary at $\sim 160-180 \mathrm{~cm}$ depth (Osborn et al., 1982; Burckle and Abrams, 1987).

There are two points to be made about these data: (1) there is a sharp, measurable drop in abundance of $C$. insignis near the end of the Gauss in two cores that have been paleomagnetically dated; and (2) in three sites, this abundance drop is accompanied by an increase in abundance of $E$. antarctica. Since this

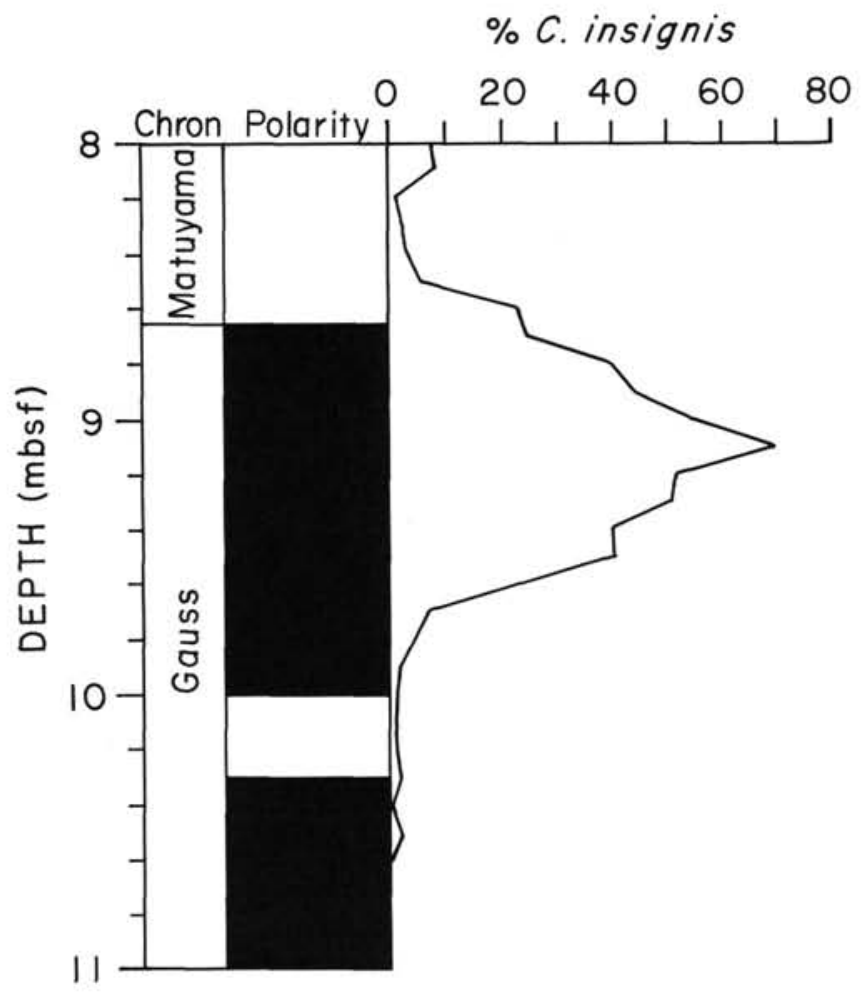

Figure 2. Abundance of Cosmiodiscus insignis in Core E13-3 from the Pacific sector of the Southern Ocean. Magnetostratigraphy is from Hays and Opdyke (1967).
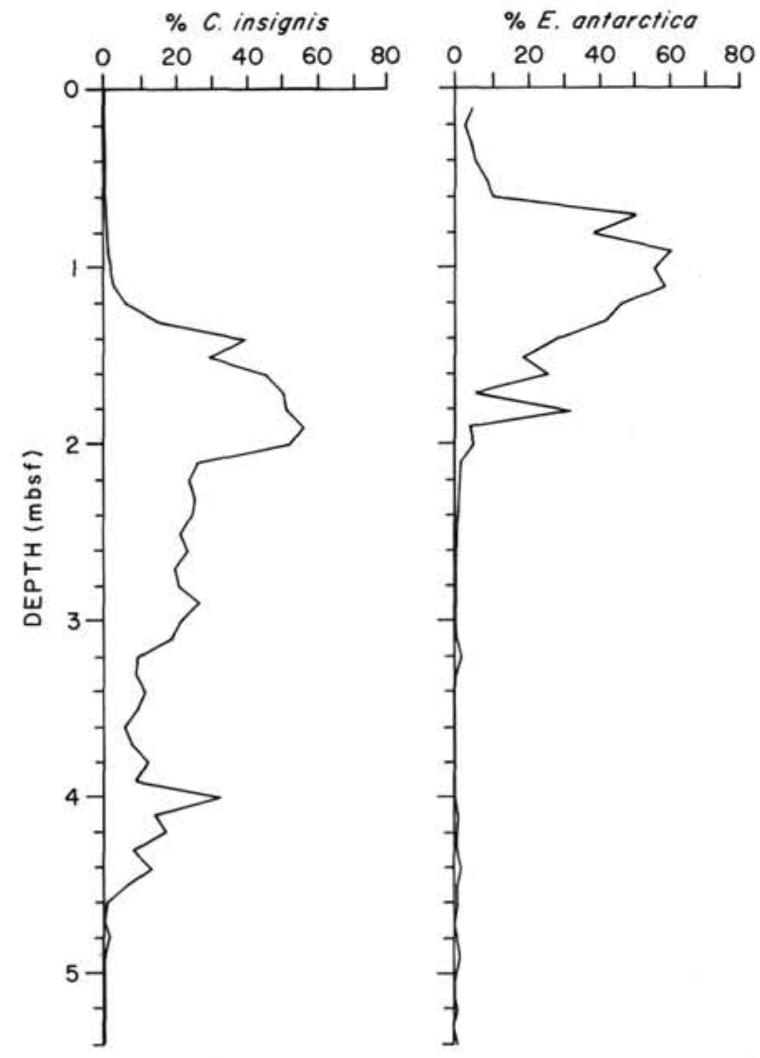

Figure 3. Abundance of $C$. insignis and Eucampia antarctica in Core E50-33 from the southeast Indian sector of the Southern Ocean. Magnetostratigraphy is from Osborn et al. (1982).

species is an ice-related form and is found in increased abundance during Pleistocene glacials (Burckle and Cooke, 1982), we relate this increase to a glacial advance. It should also be noted that the initiation of the abundance increase of $E$. antarctica comes in the late Gauss Chron, before the drop in abundance of $C$. insignis, suggesting that the initial phases in the glaciation began in the upper normal event of the Gauss and were intensified just after it.

DSDP Site 514 presents a slightly different picture (Fig. 6). Here the drop in abundance of $C$. insignis occurs some $14 \mathrm{~m}$ below the top of the Gauss and just below the first appearance datum of the radiolarian Cycladophora davisiana in the Southern Ocean (Hays et al., in press). Hays et al. (in press) have shown that this species first appears in the upper normal event of the Gauss Chron in the Southern Ocean. Our diatom data suggest one of two things: (1) the LAAD of $C$. insignis may be diachronous between the Antarctic and the Subantarctic; or (2) this diachrony may be more apparent than real and may be due to the fact that sections previously worked on were piston cores which had to have low sedimentation rates in order for the corer to penetrate to the Pliocene. Site 514 was originally selected because, among other things, the region has a relatively higher rate of sedimentation. There is also a modest, though measurable, increase in abundance of $E$. antarctica just before the abundance drop of $C$. insignis. This abundance increase becomes more pronounced just above the Gauss and was also observed in most other cores used in this study.

\section{DATA FROM SITE 697}

Holes 697A and 697B appear to have a reasonably complete section back to the lower Pliocene (Fig. 7). The Brunhes/Matuyama Chron boundary is present in the lower part of Core 113. 


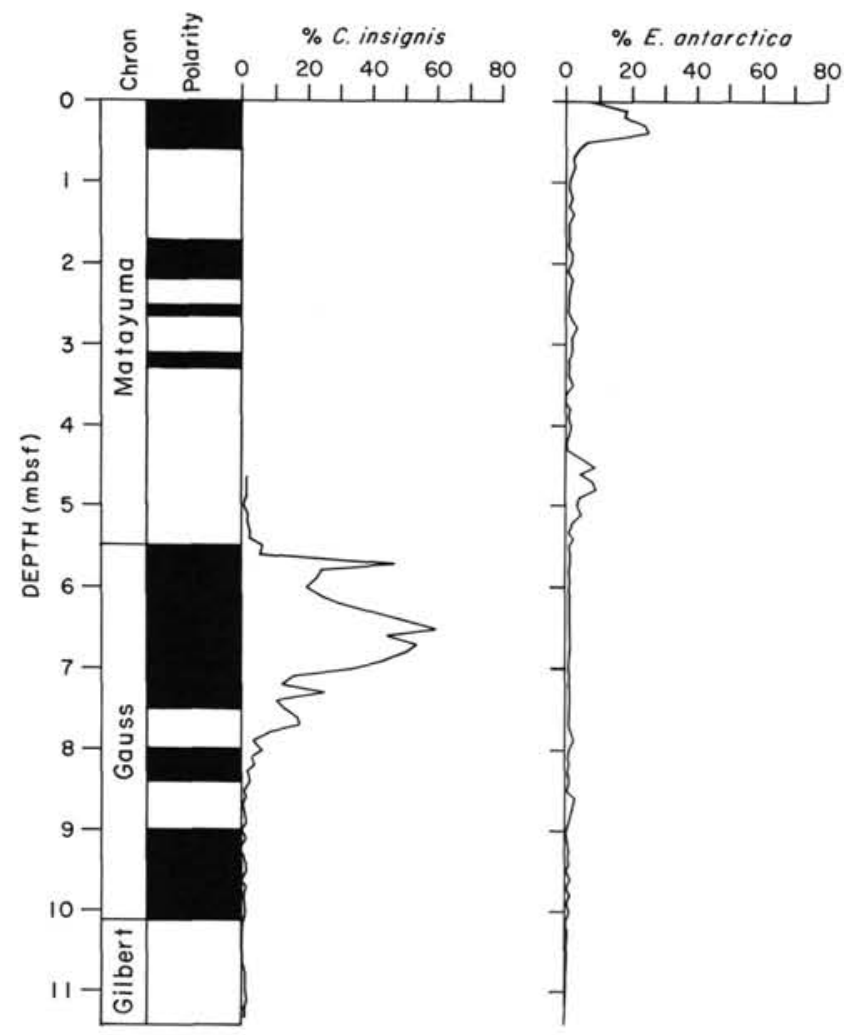

Figure 4. Abundance of $C$. insignis and E. antarctica in Core E38-8 from the southeast Indian sector of the Southern Ocean.

697B-2H (30 mbsf), both the Jaramillo and Olduvai Subchrons are present, and the Gauss/Matuyama Chron boundary is in the upper part of Core 113-697B-10H (105.7 mbsf). Similarly, the Mammoth and Kaena Subchrons are identifiable in the Gauss and the Gauss/Gilbert boundary is in the lower part of Core 113-697B-16X (164.25 mbsf). Three of the four normal Subchrons in the Gilbert are present in this site (Table 2). Although this section appears to be complete we did not observe abundant $C$. insignis in the upper Gauss. Indeed, the interval which includes the $C$. insignis zone (Ciesielski, 1983) is largely characterized by poor diatom preservation, which may be due to increased sea-ice cover. We rule out winnowing since this would remove the fragments and leave the more robust diatoms as a lag deposit. Similarly, an increase in detrital influx would not influence diatom preservation.

As also noted by Pudsey (this volume) there are cyclical occurrences of diatoms within the Brunhes between near-surface sediments and about 17 mbsf (Fig. 7). In most diatomaceous intervals $E$. antarctica predominates, but there are a few intervals where non-ice-related forms are more abundant. Diatoms are absent or in low abundance between 17 and $\sim 40$ mbsf (lower part of the Brunhes to the upper part of the Matuyama Chron, just above the Jaramillo). A short interval, centered around 50 mbsf (just below the Jaramillo) also contains diatoms, but here non-ice-related forms predominate. This is also true of the interval between $\sim 85$ and 95 mbsf (lower part of the Matuyama just below the Olduvai). Between $\sim 130$ and 160 mbsf (encom-
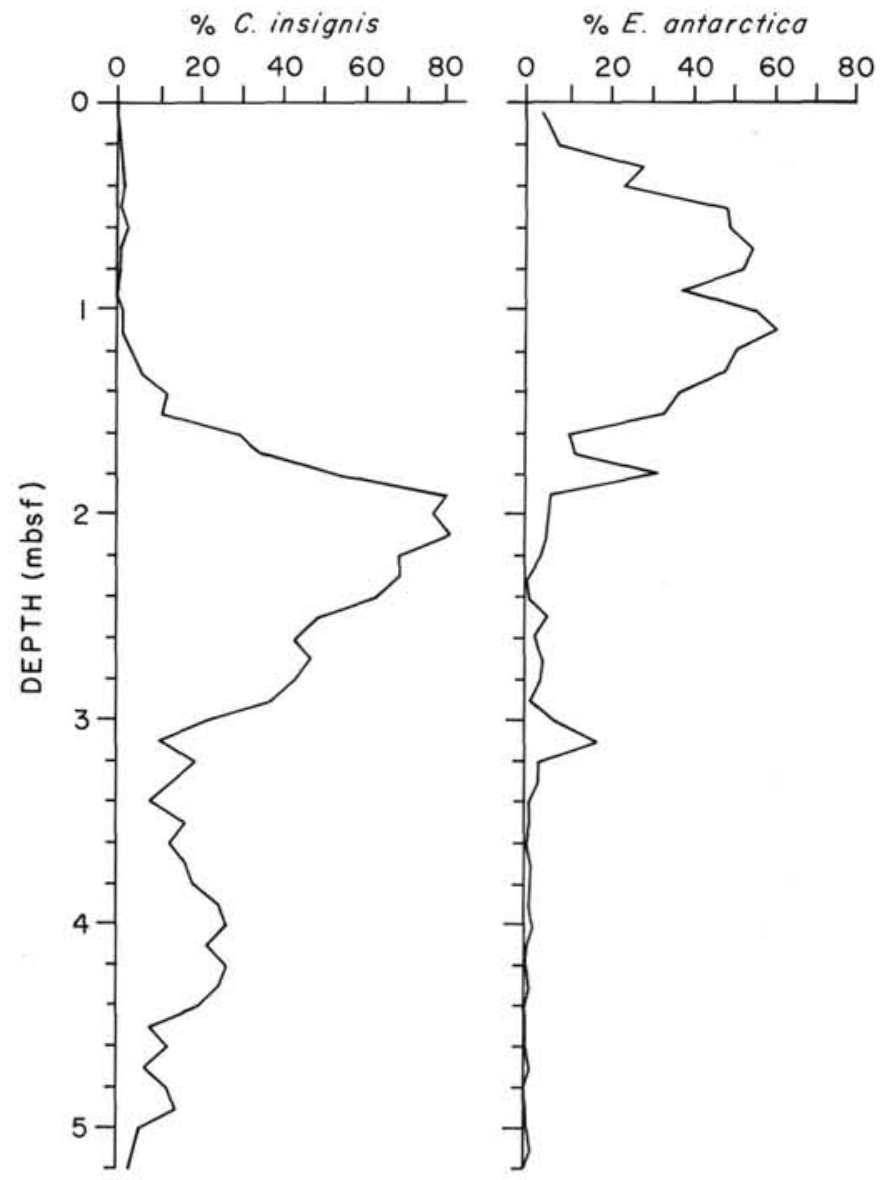

Figure 5. Abundance of $C$. insignis and E. antarctica in Core E38-7 from the southeast Indian sector of the Southern Ocean.

passing all but the upper part of the Gauss) diatoms are common to abundant. At a few levels, $E$. antarctica exceeds $50 \%$ in relative abundance, but at most levels non-ice-related forms predominate.

Percent opal ranges from about $2.5 \%$ to almost $20 \%$ in Holes 697A and 697B. Mortlock and Froelich (in press) show that the silica in clay contributes $\sim 2 \%-3 \%$ to percent opal so that opal may be present in low concentrations without diatoms or radiolaria being present. In our data set we found that percent opal may range up to $5 \%$ without diatoms or radiolaria being present, which does not seriously conflict with the results of Mortlock and Froelich (in press). Our data also confirm the conclusion of these authors that the opal content (in excess of about $5 \%$ ) reflects both the location and intensity of surface water productivity.

\section{DISCUSSION}

We can identify broad paleoclimatic trends in Site 697 and relate them to Pliocene/Pleistocene sections elsewhere in the Southern Ocean. Chief among these is our interpretation of the increase in relative abundance of the ice-related form $E$. antarctica, in the upper part of the Gauss Chron. We suggest that this occurrence, as well as upsection occurrences in the early Matuyama Chron, reflects reglaciation of Antarctica, possibly following partial deglaciation of the continent in the early Pliocene. Such a reglaciation would support a fringe of sea-ice around the continent, although it would not be as extensive as that during the late Quaternary (Burckle, 1984). While diatoms are present and percent opal is high in the early and middle 


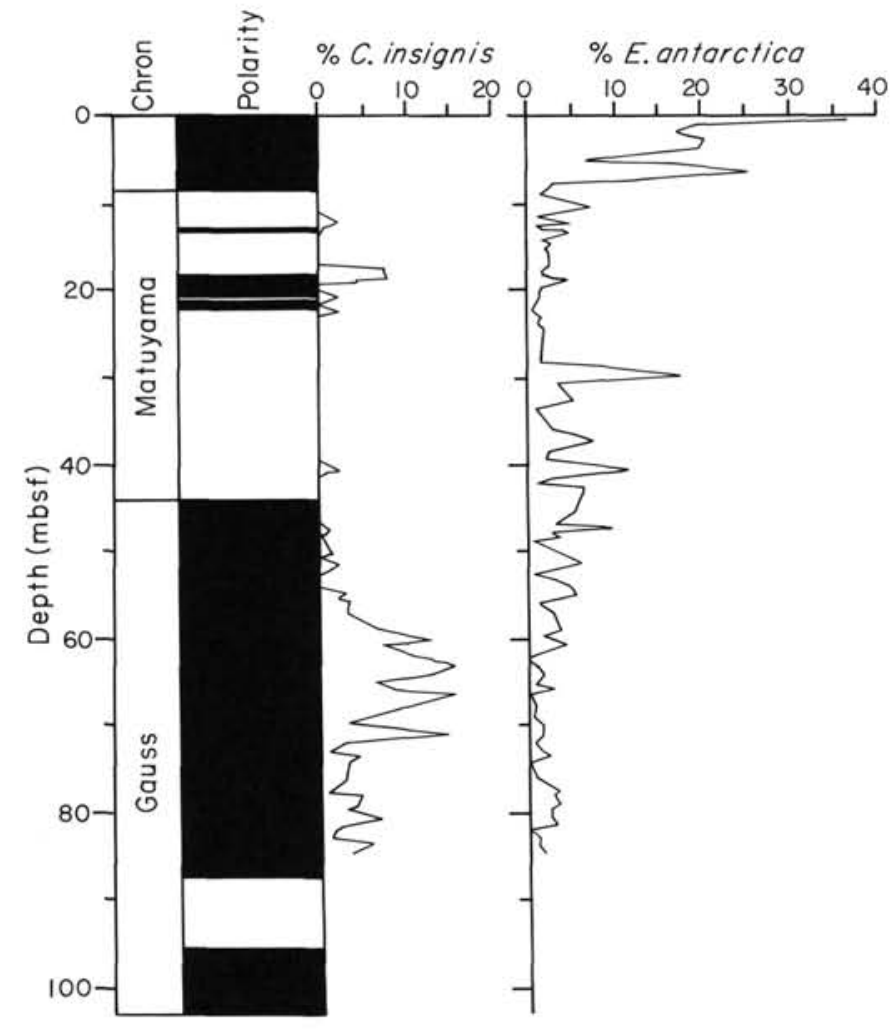

Figure 6. Abundance of $C$. insignis and E. antarctica in DSDP Site 514 from the Atlantic sector of the Southern Ocean. Magnetostratigraphy is from Salloway (1983).

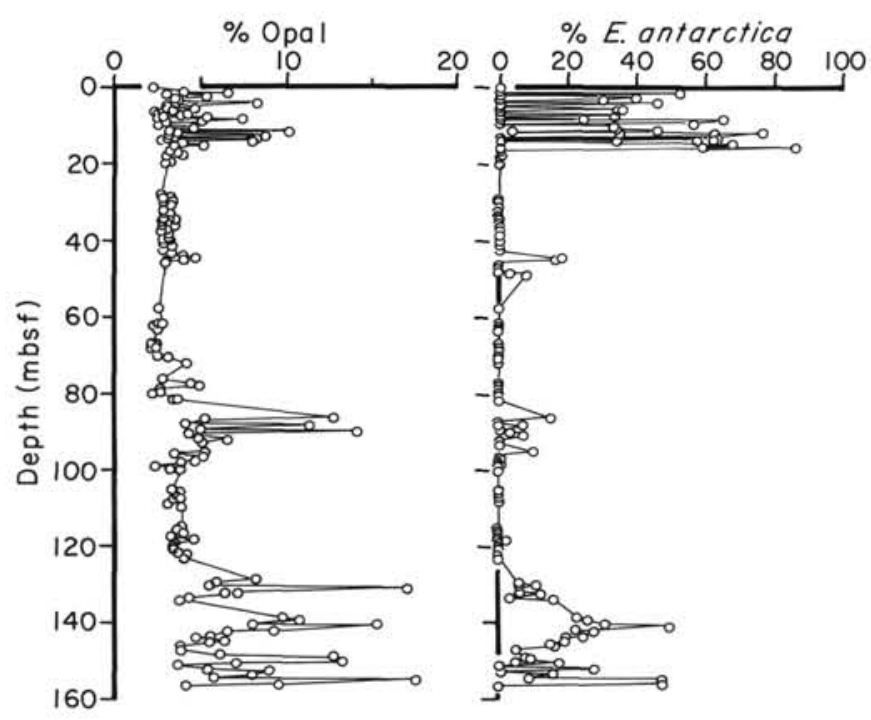

Figure 7. Percent opal plotted against abundance of $E$. antarctica in ODP Site 697 from the Jane Basin. Note that high opal content (i.e., $>5 \%$ ) is associated with the occurrence of diatoms. Refer to Table 2 for depths to magnetic reversals.
Table 2. Age and depth of magnetic reversals at Holes 697A and 697B.

\begin{tabular}{llc}
\hline \multicolumn{1}{c}{ Chron or Subchron } & Age (Ma) & $\begin{array}{c}\text { Depth } \\
\text { (mbsf) }\end{array}$ \\
\hline Blake Subchron, top & 0.105 & 2.97 \\
Blake Subchron, base & 0.155 & 4.59 \\
Brunhes Chron, base & 0.73 & 30.0 \\
Jaramillo Subchron, base & 0.98 & 42.95 \\
Olduvai Subchron, top & 1.66 & 67.8 \\
Olduvai Subchron, base & 1.88 & 86.3 \\
Matuyama Chron, base & 2.47 & 105.7 \\
C2AN-2, top & 2.99 & 132.8 \\
C2AN-2, base & 3.08 & 138.7 \\
C2AN-3, top & 3.18 & 147.6 \\
Gauss Chron, base & 3.40 & 164.25 \\
C3N-1, top & 3.88 & 201.0 \\
C3N-1, base & 3.97 & 207.5 \\
C3N-3, top & 4.40 & 247.2 \\
C3N-3, base & 4.47 & 261.0 \\
C3N-4, top & 4.57 & 295.7 \\
\hline
\end{tabular}

Gauss Chron (suggesting more open-ocean conditions), the late Gauss is marked by low percentages of opal and few or no diatoms in the sediment. This is also true for the early Matuyama Chron. If we accept spring and summer sea-ice cover as the major suppressant of diatom productivity in the Southern Ocean then we would have to conclude that sea-ice stood over Site 697 during much of the year during this time interval.

Similarly, the absence of diatoms and the low percent opal content of sediments deposited during much of the middle and later Matuyama would argue for increased sea-ice cover over the Jane Basin during this time. Warmer, open-ocean intervals are noted near the Olduvai and Jaramillo Subchrons but the bulk of our record for the Matuyama Chron support the conclusion of Westall et al. (1987) that most of this interval is characterized by extensive sea-ice cover with low seasonal contrast. Our results for the early part of the Brunhes Chron are similar, at least for the Jane Basin. During this time sea-ice cover over the basin apparently extended well into the growing season. In contrast, the later Brunhes is characterized by alternating open water (during the growing season) and extensive, almost year-round, sea-ice.

Using a sea-ice proxy as a criterion for ice build-up on the continent is also supported by data from other sites. DSDP Site 514 in the Atlantic sector shows increased relative abundance (although modest, given its distance from the continent) of $E$. antarctica in the upper part of the Gauss Chron with a larger increase just above the Gauss. With the exception of piston Core E50-33, and E13-3, all sites included in this study show an increase in relative abundance of $E$. antarctica in the upper part of the Gauss. The abrupt nature of the abundance drop of $C$. insignis and the overlying abundance increase in E. antarctica in Core E50-33 suggest to us an hiatus across the Gauss/Matuyama boundary at this site. Core E13-3 does not show any increase in abundance of $E$. antarctica in any part of the Pliocene. This is understandable since, even today, it is well outside the range of ice, either sea-ice or icebergs. Although there are no reliable paleomagnetic data for cores E38-7 and E38-8, we are reasonably sure that the biostratigraphy can be used to identify the interval between the upper part of the Gauss and the lower part of the Matuyama.

The glaciation scenario is similar to what was played out in the Northern Hemisphere. Raymo et al. (in press) point out that prior to 2.4 Ma the upper part of the Gauss Chron in the Northern Hemisphere is characterized, both sedimentologically and isotopically, by glaciations only minimally smaller and sometimes greater than some of those that occurred after $2.4 \mathrm{Ma}$. These authors further note that "the presence of ice-rafted de- 
tritus (IRD) in the North Atlantic suggests that a significant fraction of this ice must be located in the Northern Hemisphere, yet we cannot rule out the possibility of ice growth in Antarctica." We suggest that ice growth also occurred on Antarctica during this time.

\section{ACKNOWLEDGMENTS}

This work was supported by the Deutsche Forschungsgemeinschaft (to R. Gersonde) and the National Science Foundation (to L. H. Burckle).

\section{REFERENCES}

Backman, J., 1979. Pliocene biostratigraphy of DSDP Sites 111 and 116 from the North Atlantic Ocean and the age of Northern Hemisphere glaciation. Acta Univ. Stockh, Stockholm Contrib. Geol., 32:115-137.

Backman, J., and Pestiaux, P., 1987. Pliocene Discoaster abundance variations, Deep Sea Drilling Project Site 606: biochronology and paleoenvironemtal implications. In Ruddiman, W. F., Kidd, R. B., Thomas, F., et al., Init. Repts. DSDP, 94: Washington (U.S. Govt. Printing Office), 903-909.

Banahan, S., and Goering, J. J., 1986. The production of biogenic silica and its accumulation on the southeastern Bering sea continental shelf. Cont. Shelf Res., 5:199-213.

Barker, P. F., Kennett, J. P., et al., 1988. Proc. ODP, Init. Repts., 113: College Station, TX (Ocean Drilling Program).

Brewster, N. A., 1980. Cenozoic biogenic silica sedimentation in the Antarctic ocean. Geol. Soc. Am. Bull., 91:337-347.

Burckle, L. H., 1984. Diatom distribution and oceanographic reconstruction in the Southern ocean-present and last glacial maximum. Mar. Micropaleontol., 8:241-262.

Burckle, L. H., Clarke, D. B., and Shackleton, N. J., 1978. Isochronous last abundant appearance datum (LAAD) of the diatom Hemidiscus karstenii in the sub-Antarctic. Geology, 6:243-246.

Burckle, L. H., Robinson, D., and Cooke, D. W., 1982. Reappraisal of sea-ice distribution in Atlantic and Pacific sectors of the Southern ocean at 18,000 y. BP. Nature, 299:435-437.

Burckle, L. H., and Cirilli, J., 1987. Origin of diatom ooze belt in the Southern Ocean: implications for paleoceanography and paleoclimatology. Micropaleontology, 33:82-86.

Burckle, L. H., and Abrams, N., 1987. Pliocene-early Pleistocene hiatuses of the Southern Ocean-diatom evidence. Mar. Geol. 77:207-218.

Burckle, L. H., Jacobs, S. S., and McLaughlin, R., 1987. Late spring diatom distribution between New Zealand and the Ross Sea: correlation with hydrography and bottom sediments. Micropaleontology, 33:74-81.

Ciesielski, P. F., 1983. The Neogene diatom biostratigraphy DSDP Leg 71, subantarctic sediments. In Ludwig, W. J., Krasheninnikov, V. A., et al. Init. Repts. DSDP, 71: Washington (U.S. Govt. Printing Office), 635-665.

Cooke, D. W., and Hays, J. D., 1982. Estimates of Antarctic ocean seasonal sea ice during glacial intervals. In Craddock, C. (Ed.), Antarctic Geoscience: Madison. (Univ. Wisconsin Press), 1017-1025.

Einarsson, T., and Albertsson, K. J., 1988. The glacial history of Iceland during the past three million years. In Shackleton, N. J., West, R. G., and Bowen, D. Q. (Eds.), The past three million years: evolution of climate variability in the North Atlantic region: Cambridge (Cambridge Univ. Press), 227-234.

Gordon. A. L., 1971. Oceanography of Antarctic waters. In Reid, J. L. (Ed.), Antarctic Oceanology 1. Antarct. Res Ser. v., 15:169-203.

Hays, J. D., Irving, G., and King, D., in press. Phyletic and ecophenotypic changes in the radiolarian species, Cycladophora davisiana. In Bleil, U. (Ed.), Geologic History of the Arctic and Antarctic: Bremen.

Hays, J. D., and Opdyke, N. D., 1967. Antarctic Radiolaria, magnetic reversals and climatic change. Science, 158:1001-1011.

Hays, J. D., Lozano, J. A., Shackleton, N. J., and Irving, G., 1976. Reconstruction of the Atlantic and western Indian ocean sectors of the 18,000 yr. B.P. Antarctic ocean. In Cline, R. M., and Hays, J. D. (Eds.), Investigation of late Quaternary paleoceanography and paleoclimatology. Geol. Soc. Am. Mem., 145:337-372.

Heath, G. R., Hollister, C. D., Anderson, D. R., and Leinen, M., 1983. Why consider sub-seabed disposal of high-level nuclear waste? In
Park, P. K., et al. (Eds.), Radioactive Wastes in the Ocean: N.Y. (J. Wiley), 3:303-325.

Kennett, J. P., 1977. Cenozoic evolution of Antarctic glaciation, the circum-Antarctic ocean, and their impact on global paleoceanography. J. Geophys. Res., 82:3843-3860.

Leinen, M., 1979. Biogenic silica accumulation in the central equatorial Pacific and its implications for Cenozoic paleoceanography. Geol. Soc. Am. Bull., 90:1310-1376.

Leinen, M., Cwienk, D., Heath, G. R., Biscaye, P. E., Kolla, V., Thiede, J., and Dauphin, J. P., 1986. Distribution of biogenic silica and quartz in recent deep-sea sediment. Geology, 14:199-203.

Molina-Cruz, A., and Price, P., 1977. Distribution of opal and quartz in the ocean floor of the sub-tropical southeastern Pacific. Geology, 5:81-84.

Mortlock, R., and Froelich, P. N., in press. A simple method for the rapid determination of biogenic opal in pelagic marine sediments. Deep-Sea Res.

Murray, J., and Renard, A. F., 1891. Deep-sea deposits. In Report on the scientific results of the Voyage of H.M.S. Challenger during the years 1873-1876: Edinburgh (Neil and Co.), 1-525.

Osborn, N. I., Ciesielski, P. F., Ledbetter, M. T., 1982. Disconformities and paleoceanography in the southeast Indian ocean during the past 5.4 million years. Geol. Soc. Am. Bull., 94:1345-1358.

Philippi, E., 1912. Die grundproben der deutschen Sudpolar expedition 1901-1903. In Deutsche Sudpolar-Expedition 1901-1903. 2. Geographie und Geologie. Berlin, 415-616.

Pichon, J-J., Labracherie, M., Labeyrie, L. D., and Dupart, J., 1987. Transfer functions between diatom assemblages and surface hydrology in the Southern ocean. Palaeogeogr., Palaeoclimatol., Palaeoecol., 61:79-95.

Pudsey, C. J., Barker, P. F., and Hamilton, N., 1988. Weddell Sea abyssal sediments: a record of Antarctic bottom water flow. Mar. Geol., $82: 289-314$.

Raymo, M. E., Ruddiman, W. F., and Clement, B. M., 1987. PliocenePleistocene paleoceanography of the north Atlantic at Deep Sea Drilling Project Site 609. In Ruddiman, W. F., Kidd, R. B., Thomas, F., et al., Init. Repts. DSDP, 94: Washington (U.S. Govt. Printing Office), 895-901.

Raymo, M. E., Ruddiman, W. F., Backman, J., Clement, B. M., and Martinson, D. G., in press. Late Pliocene variation in Northern Hemisphere ice sheets and north Atlantic deep water circulation. Paleoceanography.

Salloway, J. C., 1983. Paleomagnetism of sediments from Deep Sea Drilling Project leg 71. In Ludwig, W. J., Krasheninnikov, V. A., et al., Init. Repts. DSDP, 71: Washington (U.S. Govt. Printing Office), 1073-1091.

Schott, W., 1939. Deep-sea sediments of the Indian ocean. In Trask, P. D. (Ed.), Recent Marine Sediments. Soc. Econ. Paleontol. Mineral. Spec. Publ., 4:398-407.

Schrader, H-J., 1974. Proposal for a standardized method of cleaning diatom-bearing deep-sea and land-exposed marine sediment. In Simonsen R. (Ed.), Third Symposium on Recent and Fossil Marine Diatoms. Nova Hedwigia., 46:403-409.

Schwerdtfeger, W., 1975. The effect of the Antarctic peninsula on the temperature regime in the Weddell Sea. Mon. Weather Rev. 103:4551.

Shackleton, N. J., Backman, J., Zimmerman, H., Kent, D. V., Hall, M. A., Roberts, D. G., and Baldauf, J., 1984. Oxygen isotope calibration of the onset of ice-rafting and history of glaciation in the North Atlantic region. Nature, 307:620-623.

Shemesh, A., Burckle, L. H., and Froelich. P. N., 1989. Dissolution and preservation of Antarctic diatoms and the effect on sediment thanatocoenosis. Quat. Res., 31:288-308.

Westall, F., Treppke, U., Fenner, J., and Froelich, P., 1987. Evidence from the south Atlantic for a change in Pleistocene climatic fluctuations near the Brunhes/Matuyama boundary; Polarstern and ODP 114. Abstr., Am. Geophys. Union. 68:1768.

Date of initial receipt: 1 March 1989

Date of acceptance: 10 October 1989

Ms 113B-203 